\title{
Chloride secretion induced by thermostable direct haemolysin of Vibrio parahaemolyticus depends on colonic cell maturation
}

\author{
AKIRA TAKAHASHI*, TETSUYA IIDA, ROCHMAN NAIM, YUTAKA NAYKAYA* and \\ TAKESHI HONDA
}

Department of Bacterial Infections, Research Institute for Microbial Diseases, Osaka University, 3-1, Yamadaoka, Suita, Osaka 565-0871 and *Department of Nutrition, School of Medicine, Tokushima University, Kuramoto-cho, 3-15-18, Tokushima 770-8503, Japan

\begin{abstract}
Vibrio parahaemolyticus produces a thermostable direct haemolysin (TDH) that has been implicated in the pathogenesis of diarrhoeal disease caused by this organism. In previous work, TDH induced $\mathrm{Cl}^{-}$secretion in human colonic epithelial cells that was dependent on the intracellular $\mathrm{Ca}^{2+}$ concentration, $\left[\mathrm{Ca}^{2+}\right]_{\text {in }}$. This study investigated whether $\mathrm{Cl}^{-}$ secretion induced by TDH is influenced by the stage of maturation of intestinal epithelial cells. Two different human colonic cell lines, villus cell-like Caco-2 cells and crypt cell-like $\mathbf{T} 84$ cells, cultured by different methods to obtain differentiated samples, were used. When these cells were exposed to butyrate, a transcriptional regulator of differentiation genes, or co-cultured with $18 \mathrm{Co}$ cells, a human colonic fibroblast cell line, they showed increased trans-epithelial resistance and villus cell marker enzyme activity. In Caco-2 cells, exposure to butyrate or co-culturing with $18 \mathrm{Co}$ cells resulted in increased TDH binding, higher short-circuit currents (Isc) and greater $\left[\mathrm{Ca}^{2+}\right]_{\text {in }}$. These results suggest that sensitivity to $T D H$ is affected by the stage of cellular differentiation of cultured intestinal epithelial cells.
\end{abstract}

\section{Introduction}

Vibrio parahaemolyticus is a widespread and important cause of gastro-enteritis, but the mechanisms underlying the diarrhoeic action of this pathogen are not completely understood. Thermostable direct haemoly$\sin (\mathrm{TDH})$ secreted by $V$. parahaemolyticus is considered to be a major virulence factor $[1,2]$ and has various biological activities, including haemolytic activity, cardiotoxicity, mouse lethality and enterotoxicity $[2,3]$. Several reports have shown that TDH induces intestinal secretion and is involved in the pathogenesis of diarrhoea caused by $V$. parahaemolyticus $[4,5]$.

Other research has indicated that TDH induces intestinal chloride secretion with an increase of $\mathrm{Ca}^{2+}$ as a second messenger in rabbit ileum [5]. In erythrocytes [6] and Intestine 407 cells [7], TDH increases the intracellular $\mathrm{Ca}^{2+}$ concentration $\left(\left[\mathrm{Ca}^{2+}\right]_{\text {in }}\right)$. The effect of TDH on human colonic

Received 4 Sept. 2000; revised version received 15 March 2001; accepted 9 April 2001.

Corresponding author: Dr A. Takahashi (e-mail: akiratak@ nutr.med.tokushima-u.ac.jp). epithelial cells follows three steps: (1) TDH binds to the epithelial cells; (2) there is an increase in $\left[\mathrm{Ca}^{2+}\right]_{\text {in }}$, which is associated with activation of protein kinase $\mathrm{C}$ (PKC); (3) $\mathrm{Cl}^{-}$secretion is stimulated, as indicated by increased short-circuit currents (Isc) [8]. Thus, TDHinduced $\mathrm{Cl}^{-}$secretion, which depends on $\left[\mathrm{Ca}^{2+}\right]_{\text {in }}$, is one of the reasons why $V$. parahaemolyticus infection induces diarrhoea.

Reports have shown that $V$. parahaemolyticus attaches to the rabbit intestinal brush border [9] and to Caco-2 cells [10] which are differentiated to the mature villus epithelium [11]. On the other hand, V. parahaemolyticus attaches to $\mathrm{M}$ cells but has a poor affinity for the villus cells in the human small intestine [12]. However, the target of $V$. parahaemolyticus is still not clearly defined in the human colonic epithelium. TDH added on the mucosal side did not stimulate $\mathrm{Cl}^{-}$secretion or increase $\mathrm{Ca}^{2+}$ in T84 cells, a human colonic crypt-like cell line [13]. Crypt cells are relatively undifferentiated proliferating cells. However, as they migrate up the villus, intestinal cells differentiate and acquire the enzymic and morphological characteristics of mature villus epithelium $[14,15]$. TDH increased $\mathrm{Cl}^{-}$secretion when added to Caco-2 cells that were stimulated to 
differentiate by treatment with butyrate. Recently, sensitivity to Shiga toxin (STX), which also induces diarrhoea, has been associated with cell differentiation [14]. As cells mature, they express receptors to which STX can adhere and sensitivity to STX depends on the extent to which these receptors are expressed. There have been no reports as to whether intestinal cells differ in sensitivity to TDH depending on their stage of differentiation.

To investigate the effect of TDH, Caco-2 cells and T84 cells were prepared under different conditions: (1) in simple cultures; (2) by addition of butyrate to the simple cultures; (3) by co-culturing with $18 \mathrm{Co}$ cells; (4) by a combination of butyrate addition and coculturing with $18 \mathrm{Co}$ cells. Butyrate is normally found in the intestinal lumen and induces the increased differentiation of many types of cells [15-18] including Caco-2 cells $[14,16,17]$. The $18 \mathrm{Co}$ cell line is a human colonic cell line that exhibits most of the known characteristics of intestinal subepithelial myofibroblasts in situ. It has been suggested that these cells are a source of differentiation factors that can have an effect on water or $\mathrm{Cl}^{-}$secretion from epithelial cells $[19,20]$. The stages of differentiation were assessed by examining changes in enzymic activities that are readily detected on colonic villus $[14,15,21]$. In this study, the effects of TDH on $\mathrm{Cl}^{-}$secretion, $\left[\mathrm{Ca}^{2+}\right]_{\text {in }}$ and TDH binding with these various differentiated human colonic cells were examined.

\section{Materials and methods}

Cells

T84, Caco-2 and 18Co cells were purchased from the American Type Culture Collection (Rockville, MD, USA). T84 cells, derived from human colon carcinoma, develop crypt cell-like properties during growth to confluence. Caco-2 cells are also derived from human colon carcinoma, but develop villus cell-like properties during growth to confluence. 18Co cells were derived originally from a colonic mucosal biopsy of a 2-monthold female infant. All cell lines were maintained in Eagles' Minimal Essential Medium supplemented with fetal bovine serum (FBS) $10 \% \mathrm{v} / \mathrm{v}$, gentamicin $100 \mathrm{U} / \mathrm{ml}$ and non-essential amino acids $1 \%$. The medium and supplements were obtained from Gibco BRL (Gaithersburg, MD, USA). Cells were grown in $75-\mathrm{cm}^{2}$ flasks in air with $\mathrm{CO}_{2} 5 \%$ at $37^{\circ} \mathrm{C}$, fed every 2 days and passaged weekly. To promote differentiation, cells were cultured in different ways (Fig. 1). Stock cells, consisting of Caco-2 cells or T84 cells, were trypsinised and suspended at $2 \times 10^{5}$ cells $/ \mathrm{ml}$ in medium. Cells were seeded at confluent density on to $1.0-\mathrm{cm}^{2}$ transwell inserts (Costar, Cambridge, MA, USA) (Fig. 1A and B). After the Caco-2 or T84 cells had been cultured for 2 days, butyrate was added to the culture medium (Fig. 1B and D). 18Co cells were inoculated on the reverse side of the filter in the transwell inserts (Fig. 1C-F). After these cells had been cultured for 2 days, Caco- 2 or T84 cells were

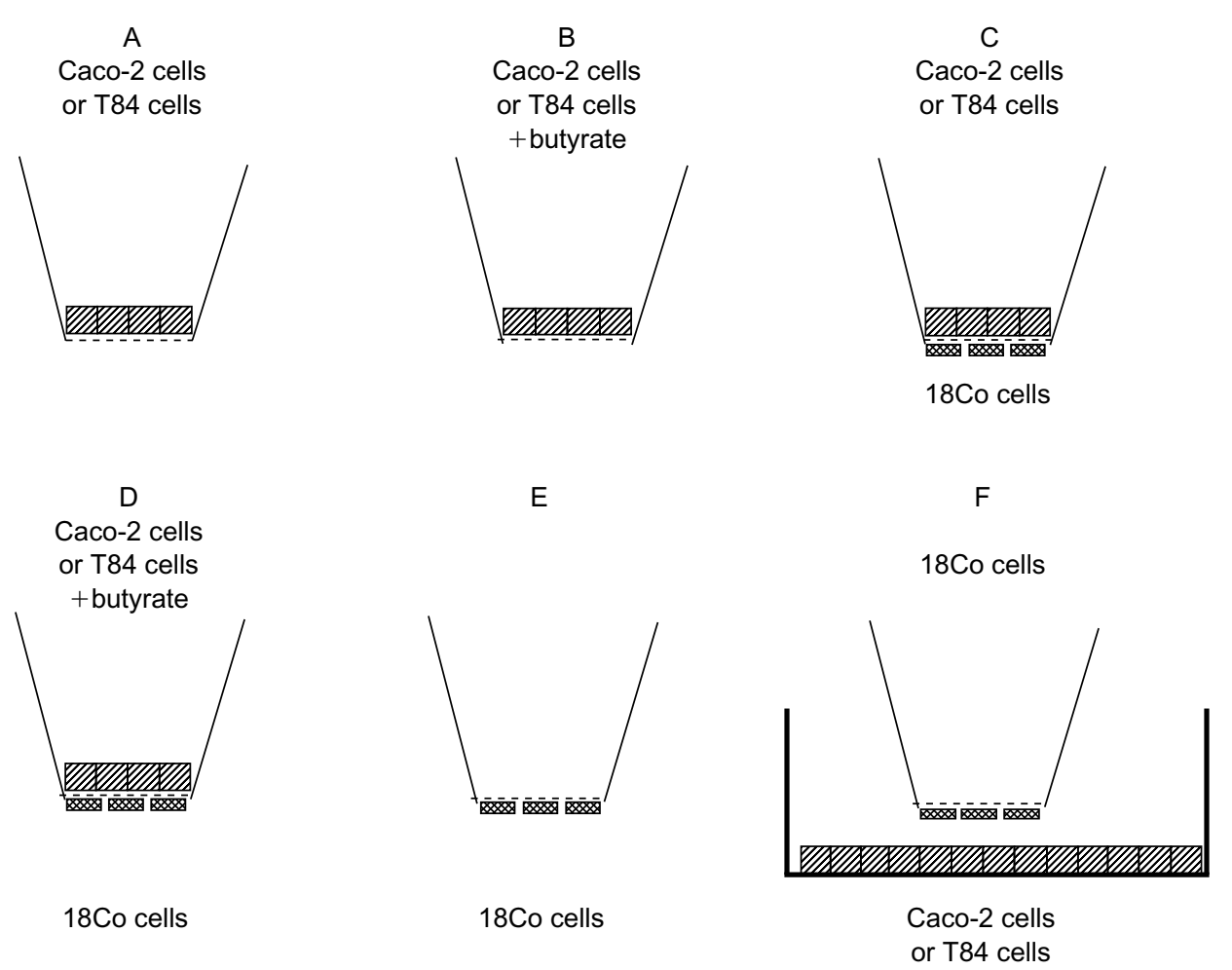

Fig. 1. Methods of cell culturing on transwell inserts. (A) Caco-2 cells or T84 cells in simple culture; (B) butyrate added to the simple culture medium after 2 days; (C) $18 \mathrm{Co}$ cells cultured on the lower side of the transwell insert filters and Caco-2 cells or T84 cells cultured on the other side of the same filter; (D) butyrate added to the culture medium after 2 days, as in (C); (E) 18Co cells cultured on the lower side of the transwell insert filters; (F) 18 Co cells cultured on the lower side of transwell insert filters and Caco-2 cells or T84 cells cultured on the floor in a 12-well plate (see Materials and methods). 
inoculated on the other side of the filter in the same transwell inserts (Fig. 1C and D) or on to the base of 12-well culture plates (Fig. 1F). After the Caco-2 cells and T84 cells had been cultured for a total of 6 days, transwell inserts with cultured cells were used for trans-epithelial resistance measurements and the Ussing chamber experiments. The effects of TDH on T84 cells from passages $50-80$, Caco-2 cells from passages $30-$ 55 and 18 Co cells from passages 4-12 were investigated.

\section{Trans-epithelial resistance measurements}

The trans-epithelial resistance of cells cultured on the transwell inserts was measured with an electrical voltmeter (EVOM, WPI, Sarasota, FL, USA).

\section{Isolation of $T D H$}

Recombinant plasmid pKK223-3, which harbours the structural gene of wild-type TDH (pT101), was introduced into Escherichia coli JM109 by transformation. Transformants were cultivated at $37^{\circ} \mathrm{C}$ for $16 \mathrm{~h}$ with rotary shaking in Luria-Bertani Broth (Bacto-tryptone, Difco, $1 \%$; yeast extract, Difco, $0.5 \% ; \mathrm{NaCl} 0.5 \%$ containing ampicillin $100 \mu \mathrm{g} / \mathrm{ml}$. Recombinant toxin was purified by a previously reported method [22]. Fractions containing TDH were assayed by haemolysis on rabbit blood agar plates [23]. The purity of samples was evaluated by SDS-PAGE by the method of Laemmli [24].

\section{Intracellular $\mathrm{Ca}^{2+}$ measurements}

The concentration of intracellular free $\mathrm{Ca}^{2+}$ was evaluated by microfluorimetry, with the fluorescent dye 1-(2-(5'-carboxyoxazol-2'-yl)-6-aminobenzofuran5-oxy)-2(2'amino-5'-methylphenoxy)ethane-N,N, $\mathrm{N}^{\prime}, \mathrm{N}^{\prime}$ tetraacetic acid, pentaacetoxy methyl ester (Fura-2/AM) at excitation wavelengths of $340 \mathrm{~nm}$ and $380 \mathrm{~nm}$ and at an emission wavelength of $510 \mathrm{~nm}$ with a specially designed chamber and an ARGUS-50/CA system (Hamamatsu Photonicus, Japan). The cells were cultured on coverslips $(18 \times 18 \mathrm{~mm})$ for 6 days. At the end of this period, each sample was loaded with Fura2/AM $(2 \mu \mathrm{M})$ (Molecular Probes, Eugene, OR, USA) for $30 \mathrm{~min}$ and washed twice with PBS. Coverslips were inserted into the chamber and each series of measurement was completed in $30 \mathrm{~min}$.

\section{Ussing chamber experiments}

To measure the trans-epithelial Isc, the bath solution contained (mM) $120 \mathrm{NaCl}, 25 \mathrm{NaHCO}_{3}, 3.3 \mathrm{KH}_{2} \mathrm{PO}_{4}$, $0.8 \mathrm{~K}_{2} \mathrm{HPO}_{4}, 1.2 \mathrm{MgCl}_{2}, 1.2 \mathrm{CaCl}_{2}$ and 10 glucose. The $\mathrm{pH}$ of this solution was 7.4 at $37^{\circ} \mathrm{C}$ when gassed with a mixture of $\mathrm{O}_{2} 95 \%$ and $\mathrm{CO}_{2} 5 \%$. Transwell cell culture inserts, with the cultured cells, were mounted in an Ussing chamber (laboratory-made) and the tissue samples were continuously short-circuited with a voltage and current clamp amplifier (Model DVC1000-E; World Precision Instruments, FL, USA). After compensation for fluid resistance, trans-epithelial resistance was measured by applying a $5-\mathrm{mV}$ pulse at 40-50-s intervals, and the resistance was calculated by using Ohm's law. TDH, 4,4'-diisothiocyanatostilbene2,2'-disulphonic acid (DIDS), glybenclamide and 5nitro-2-(3-phenylpropylamino)benzoic acid (NPPB) (all from Sigma) were added only to the mucosal bath solution in the Ussing chamber at the concentrations indicated.

\section{Enzyme assays}

Alkaline phosphatase. After they had been cultured for 6 days in transwell inserts, the cell samples were washed twice with PBS. Then, $100 \mu$ l of $p$-nitrophenyl phosphate $(1 \mathrm{mg} / \mathrm{ml}$ in $100 \mathrm{mM}$ Tris- $\mathrm{NaCl}$ buffer, $\mathrm{pH}$ 9.5, containing $5 \mathrm{mM} \mathrm{MgCl}$ ) were added to right side of each transwell insert and PBS to the other side. After incubation for $10 \mathrm{~min}$ at room temperature, the absorbance at $405 \mathrm{~nm}\left(\mathrm{~A}_{405}\right)$ was measured and compared with that from cells without substrate. Activity was expressed as the relative increase in $\mathrm{A}_{405}$ compared with the control. After measuring the alkaline phosphatase activity, cell numbers were counted after the cells were digested with trypsin.

Sucrase. After the Caco- 2 cells or T84 cells had been cultured for 6 days in transwell inserts, they were washed as above, then $100 \mu 1$ of $0.3 \mathrm{M}$ sucrose in $0.1 \mathrm{M}$ $\mathrm{KPO}_{4}$ buffer, $\mathrm{pH}$ 6.0, were added to right side of each transwell insert and PBS to the other side, after which the samples were incubated at $37^{\circ} \mathrm{C}$ for $30 \mathrm{~min}$. Liberated glucose was detected with a V-glucase kit (Nissui, Japan). The $\mathrm{A}_{520}$ of a glucose standard $1 \mathrm{mg} / \mathrm{ml}$ was 0.367 . Activity was expressed as the $\mathrm{A}_{520}$ against the cell count in the sample.

\section{Immunofluorescence staining}

T84 cells or Caco- 2 cells were grown on $18 \times 18$-mm coverslips (Matsunami, Osaka, Japan) by simple culture for 4 days, butyrate was added and 2 days after butyrate addition they were co-cultured with $18 \mathrm{Co}$ cells for 6 days. Then the cells were washed and fixed with methanol : acetic acid $(1: 1)$ and incubated at $37^{\circ} \mathrm{C}$ for $3 \mathrm{~h}$ with TDH $10 \mu \mathrm{g} / \mathrm{ml}$. The cells were washed with PBS and incubated for $1 \mathrm{~h}$ with rabbit polyclonal antibody to TDH [1] (1 in 1000 dilution in PBS solution). The cells were washed again and incubated for $1 \mathrm{~h}$ with rhodamine-conjugated anti-rabbit $\mathrm{IgG}$ antibody ( 1 in 1000 dilution in PBS) (Gibco BRL). The coverslips were removed, thoroughly washed with PBS containing bovine serum albumin $0.1 \%$ and examined by fluorescence microscopy. 


\section{Other chemicals}

Guaranteed reagent grade inorganic salts were purchased from Wako Pure Chemicals (Tokyo, Japan).

\section{Statistical evaluations}

The data were evaluated by the Student's $t$ test for unpaired samples, and $\mathrm{p}<0.05$ was considered significant.

\section{Results}

\section{Effect of butyrate or co-culture on trans-epithelial resistance}

Trans-epithelial resistance increased with the time of cell culture (Fig. 2). The resistance of $18 \mathrm{Co}$ cells, cultured on the reverse side of the transwell inserts and with the Caco- 2 cells or T84 cells cultured on the base of the plate, did not change (Fig. 2). T84 cells had a higher trans-epithelial resistance than Caco-2 cells. Both Caco-2 cells and T84 cells which had been exposed to butyrate or co-cultured with $18 \mathrm{Co}$ cells had a higher trans-epithelial resistance than samples cultured without these additions. Peak resistance values occurred after culture for 5-7 days and decreased gradually thereafter (Fig. 2). Thus, for subsequent studies, cells that had been cultured for 6 days were used.

\section{Effect of butyrate or co-culture on enzyme activity}

To assess the extent of cell differentiation to villus-like cells, alkaline phosphatase and sucrase activity were measured (Fig. 3) [14, 15, 21]. Sucrase activity increased after treatment with butyrate or co-culturing with $18 \mathrm{Co}$ cells and activity in Caco-2 cells was slightly higher than in T84 cells (Fig. 3a). Alkaline phosphatase activity in Caco-2 cells was higher than in T84 cells. After treatment with butyrate or coculturing, alkaline phosphatase activity in Caco-2 cells increased substantially (Fig. 3b). The greatest alkaline phosphatase activity was recorded in samples of Caco2 cells co-cultured with $18 \mathrm{Co}$ cells. These results indicate that Caco-2 cells that had been exposed to butyrate or to $18 \mathrm{Co}$ cells differentiated more toward the villus-like cells than T84 or Caco- 2 cells in simple culture. Trans-epithelial resistance of Caco-2 cells or T84 cells that were exposed to butyrate or co-cultured with 18 Co cells was higher (Fig. 3c) than in samples cultured without these treatments. The number of Caco-2 cells or T84 cells $/ \mathrm{cm}^{2}$ did not vary significantly between the four different culture methods.

\section{Effects of TDH}

Fig. 4a shows the effects of TDH $10 \mu \mathrm{g} / \mathrm{ml}$ on transepithelial Isc of T84 cells cultured by the four different methods shown in Fig. 1A-D. T84 cells in simple culture did not show any increase in Isc. There was a
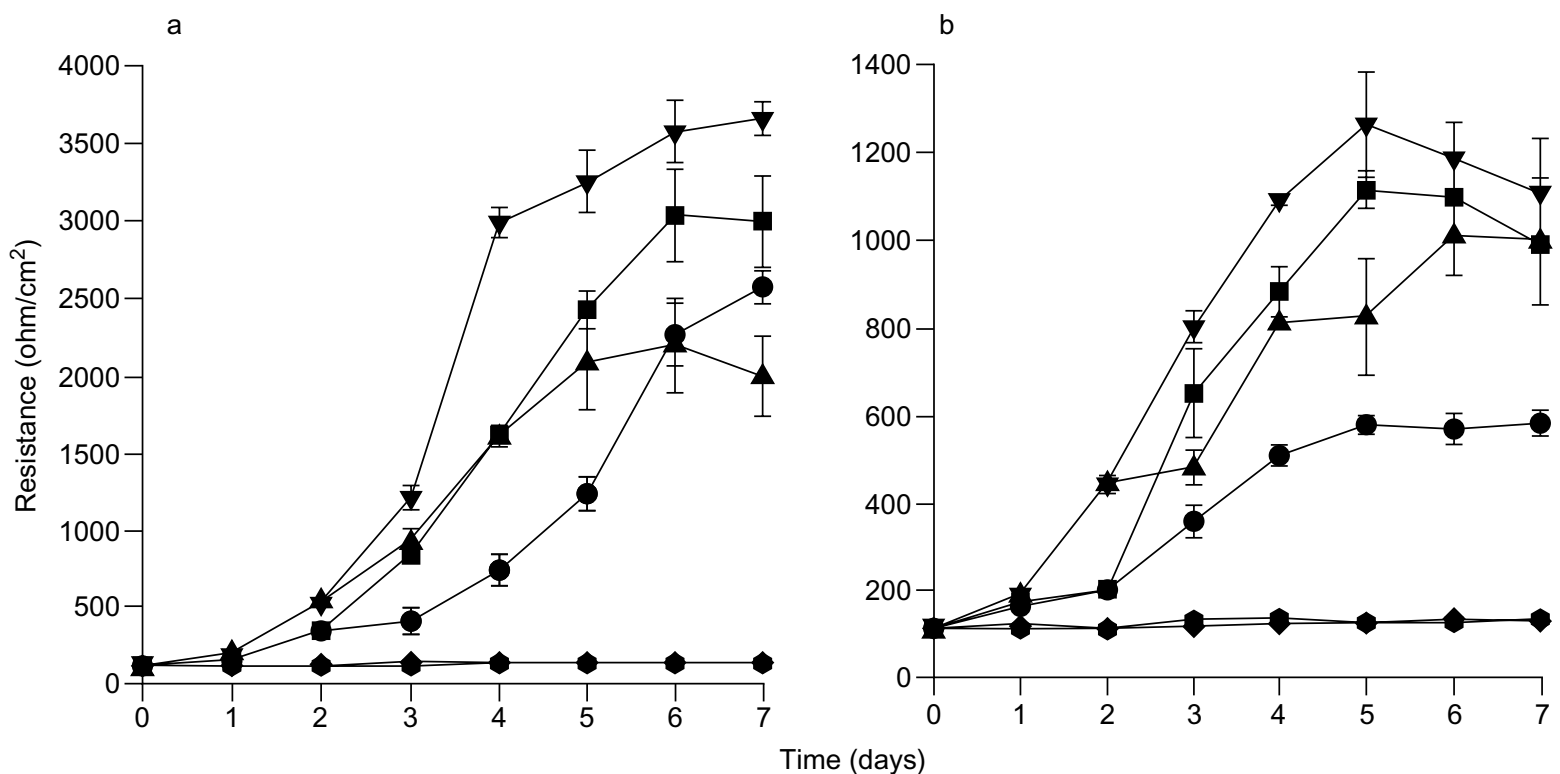

Fig. 2. Changes in trans-epithelial resistance according to number of days of culturing. (a) •, T84 cells cultured by method in Fig. 1A; $\mathbf{n}$, T84 cells cultured by the method in Fig. 1B; $\boldsymbol{\Delta}$, T84 cells and 18Co cells cultured by the method in Fig. 1C; $\boldsymbol{\nabla}$, T84 cells and 18Co cells cultured by the method in Fig. 1D; $\diamond$, 18Co cells cultured by the method in Fig. 1E; , 18Co cells cultured with T84 cells by the method in Fig. 1F. (b) $\bullet$, Caco-2 cells cultured by the method in Fig. 1A; Caco-2 cells cultured by the method in Fig. 1B; $\boldsymbol{\Delta}$, Caco-2 cells and 18 Co cells cultured by the method in Fig. 1C; $\nabla$, Caco-2 cells and 18Co cells cultured by the method in Fig. 1D; $\diamond$, 18Co cells cultured by the method in Fig. 1E; , 18Co cells cultured with Caco-2 cells by the method in Fig. 1F. Values are expressed as mean and $\operatorname{SD}(\mathrm{n}=5)$. 
a

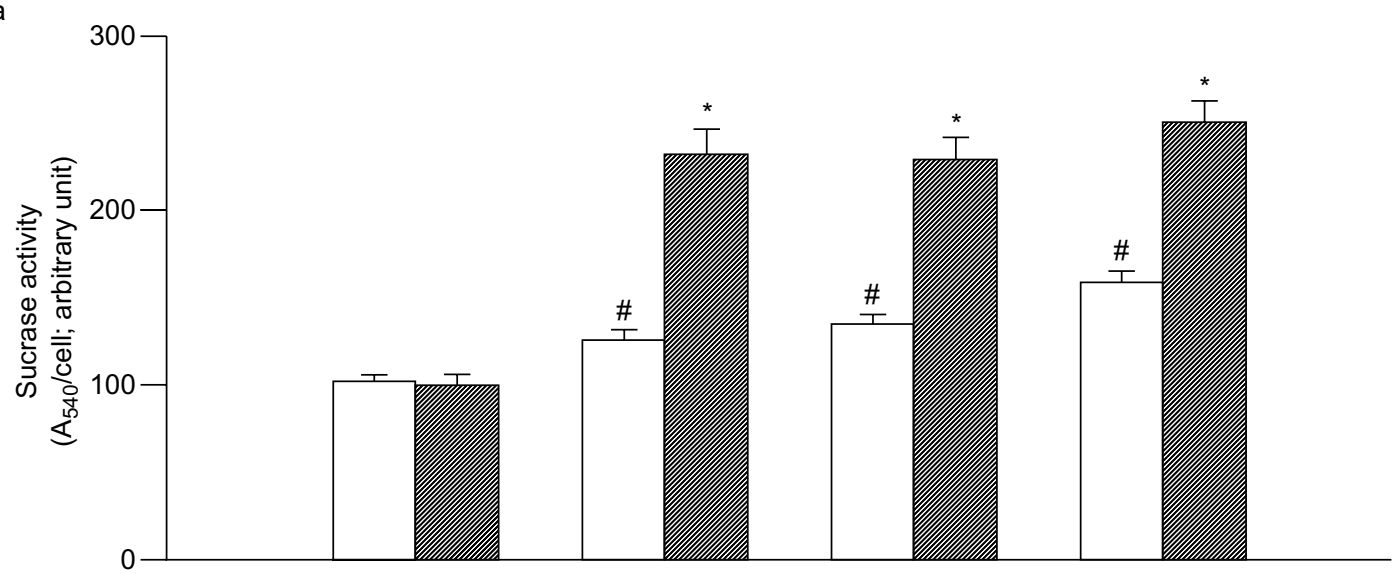

b

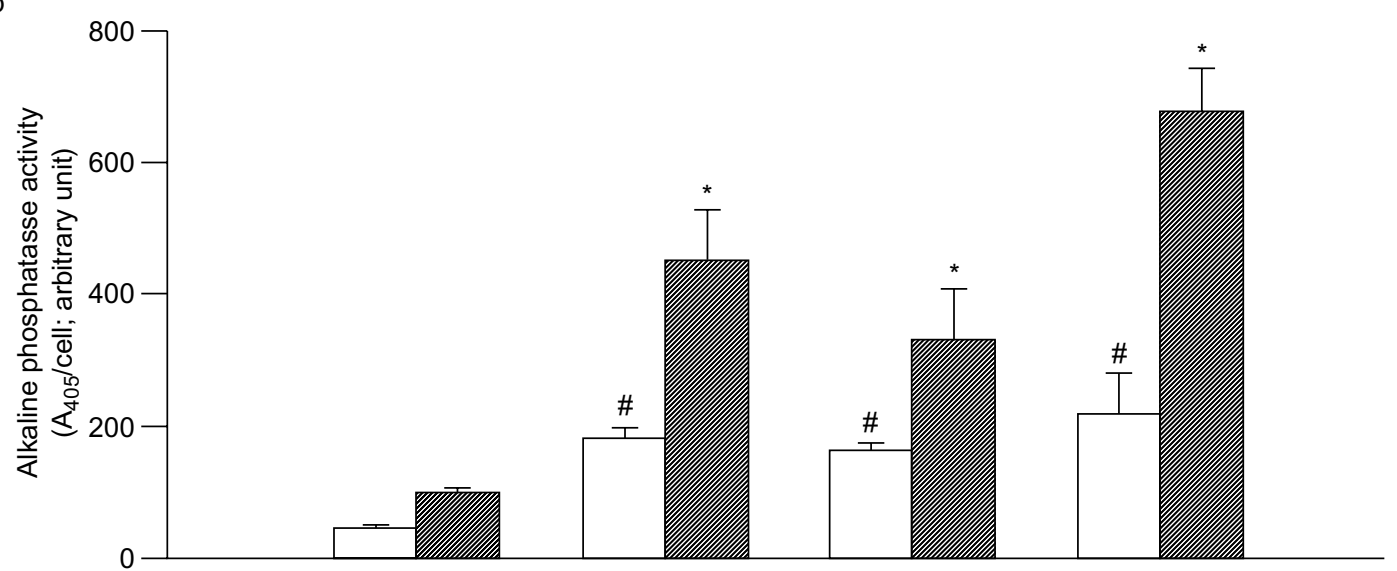

c

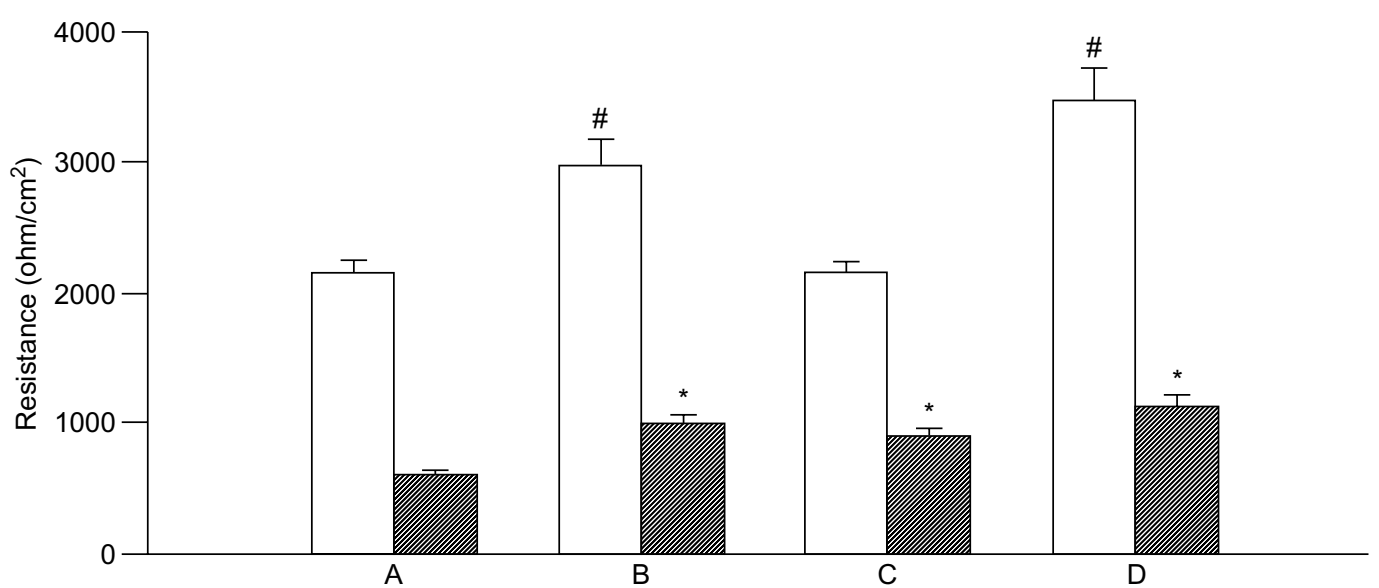

Fig. 3. Effects of exposure to butyrate or co-culturing with $18 \mathrm{Co}$ cells, or both, on enzyme activities and transepithelial resistance. $\square$, T84 cells cultured on the upper side of the transwell inserts. $\mathbb{Z}$, Caco- 2 cells cultured on the upper side of the transwell inserts. (A) Cells cultured by the method in Fig. 1A; (B) cells cultured by the method in Fig. 1B; (C) cells cultured by the method in Fig. 1C; (D) cells cultured by the method in Fig. 1D. (a) Sucrase activity of T84 cells or Caco-2 cells. (b) Alkaline phosphatase activity of T84 cells or Caco-2 cells. (c) Trans-epithelial resistance of T84 cells or Caco-2 cells. All cell samples were cultured for 6 days. Values are expressed as mean and $\mathrm{SD}(\mathrm{n}=5)$. ${ }^{*}$ Significant difference $\mathrm{p}<0.05$ ( $t$ test) versus (A) Caco-2 cells. \#Significant difference $\mathrm{p}<0.05(t$ test) versus (A) T84 cells.

readily detectable Isc increase after TDH was added to T84 cells that had been exposed to butyrate or cocultured with $18 \mathrm{Co}$ cells. Fig. $4 \mathrm{~b}$ shows the effects of $\mathrm{TDH}$ on the trans-epithelial Isc of Caco- 2 cells cultured by the four different methods. With Caco- 2 cells treated with butyrate or co-cultured with $18 \mathrm{Co}$ cells, the Isc increase was greater than with similarly treated T84 cells. Caco- 2 cells in simple culture did not show 
A

a

$\stackrel{\text { TDH }}{\downarrow}$

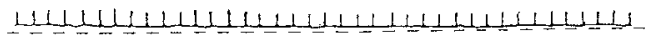

b

$\mathrm{TDH}$

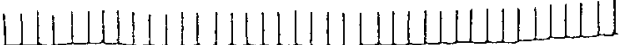

B<smiles>[3H][TeH]</smiles>

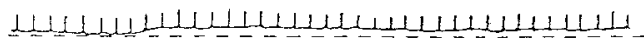

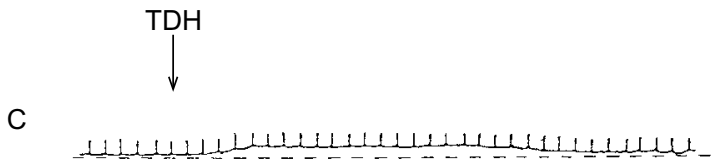

$\stackrel{\text { TDH }}{\downarrow}$

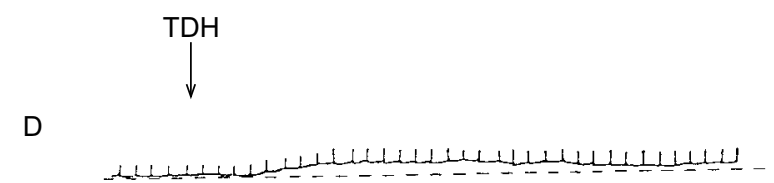

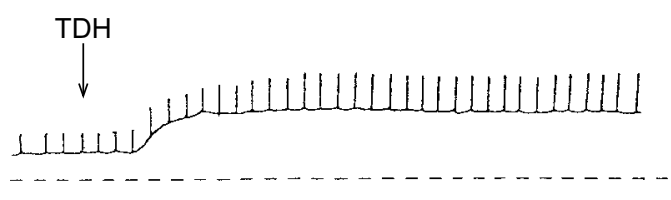
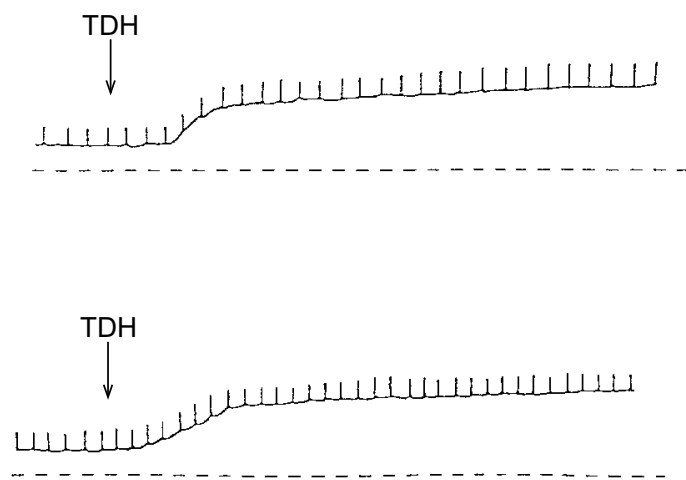

$20 \mu \mathrm{A} / \mathrm{cm}^{2} \frac{}{2 \min }$

Fig. 4. Typical changes in Isc after adding TDH $10 \mu \mathrm{g} / \mathrm{ml}$ to the mucosal side of T84 or Caco-2 cells that had been cultured for 6 days on transwell inserts. (A) Cells cultured by the method in Fig. 1A; (B) cells cultured by the method in Fig. 1B; (C) cells cultured by the method in Fig. 1C; (D) cells cultured by the method in Fig. 1D. (a) T84 cells cultured on the upper side of transwell inserts; (b) Caco-2 cells cultured on the upper side of transwell inserts.

any increase in Isc. These results suggest that the increase in Isc that followed exposure to TDH occurred only in cells that had matured into villus-like epithelia.

\section{Effect of $\mathrm{Cl}^{-}$channel inhibitors on Isc increase by $T D H$}

Fig. 5 shows the effects of $\mathrm{Cl}^{-}$channel inhibitors on Isc of samples that had been exposed to TDH. Fig. 5a shows data for T84 cells cultured by the four methods as shown in Fig. 1A-D. There was a small increase in Isc for simply cultured T84 cells; however, for Caco-2 cells cultured without additional treatment, $\mathrm{Cl}^{-}$channel inhibitors had very little effect. Caco-2 cells that had been exposed to butyrate or co-cultured with $18 \mathrm{Co}$ cells, or both, showed increased Isc (Fig. 5b). In these samples, Isc stimulated by TDH was inhibited by DIDS, an inhibitor of the $\mathrm{Ca}^{2+}$-dependent $\mathrm{Cl}^{-}$channel $[25,26]$ and the inhibition in cells cultured by the three different methods (Fig. 1B-D) was similar. Glybenclamide, an inhibitor of cAMP-dependent $\mathrm{Cl}^{-}$channel $[27,28]$, and NPPB, an inhibitor of the $\mathrm{Cl}^{-}$channel $[25,27]$, did not affect Isc (Fig. 5b).

\section{Effect of TDH on intracellular $\mathrm{Ca}^{2+}$ concentration}

In Caco-2 cells that had been treated with butyrate or co-cultured with $18 \mathrm{Co}$ cells, or both, the intracellular $\mathrm{Ca}^{2+}$ concentration increased (Fig. 6b). On the other hand, the $\left[\mathrm{Ca}^{2+}\right]_{\text {in }}$ concentration changed very little in T84 cells, even after exposure to butyrate or coculturing with $18 \mathrm{Co}$ cells (Fig. 6a). These results suggest that the increase in the $\left[\mathrm{Ca}^{2+}\right]_{\text {in }}$ that followed exposure to TDH occurred only in cells that had matured into villus-like epithelia.

\section{Binding of TDH to cell monolayers}

Immunofluorescence staining of the cell monolayers with rabbit anti-TDH and rhodamine-conjugated antirabbit IgG indicated that $\mathrm{TDH}$ bound more efficiently to Caco-2 cells that had been exposed to butyrate or co-cultured with $18 \mathrm{Co}$ cells, or both, than to T84 cell monolayers or Caco-2 cell monolayers in simple culture (data not shown). 

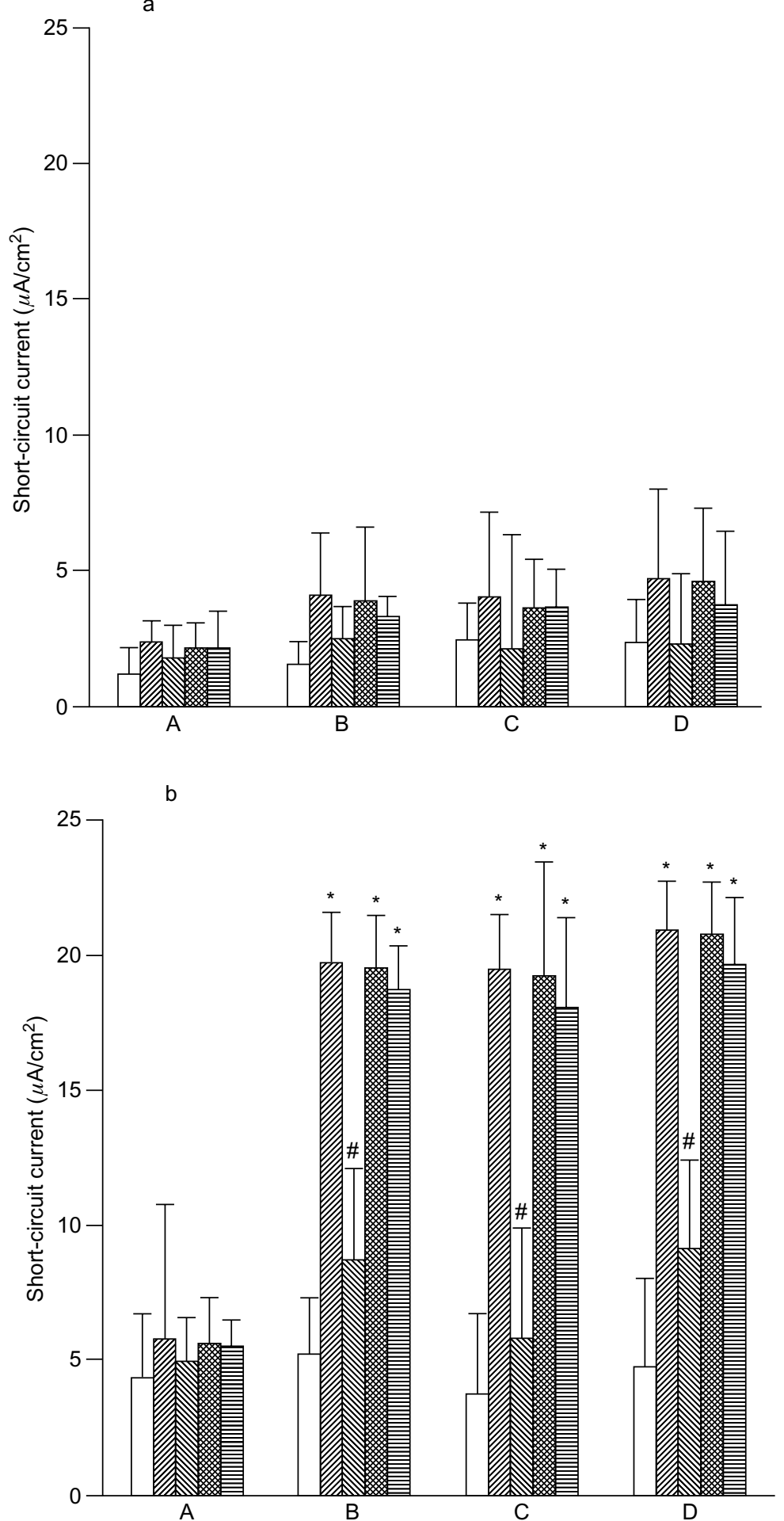

Fig. 5. Changes in Isc after adding TDH $10 \mu \mathrm{g} / \mathrm{ml}$ on the mucosal side of T84 or Caco-2 cells that had been cultured for 6 days. (a) T84 cells cultured on the upper side of Transwell inserts; (b) Caco-2 cells cultured on the upper side of transwell inserts. (A) Cells cultured by the method in Fig. 1A; (B) cells cultured by the method in Fig. 1B; (C) cells cultured by the method in Fig. 1C; (D) cells cultured by the method in Fig. 1D. $\square$, baseline; $\mathbb{Z}$, TDH added on the mucosal side of the T84 cells or Caco-2 cells (Isc was measured 15 min after TDH addition). $\mathbb{\nabla}$, TDH added, then DIDS added on the mucosal side (Isc was measured $15 \mathrm{~min}$ after DIDS addition). TDH added, then glybenclamide added and Isc was measured after $15 \mathrm{~min}$. $\Xi$, TDH added, then NPPB added and Isc measured after $15 \mathrm{~min}$. ${ }^{*}$ Significant difference $\mathrm{p}<0.05$ ( $t$ test) versus each of the baseline values $(\square)$. \#Significant difference $\mathrm{p}<0.05(t$ test) versus each of the TDH values $(\mathbb{Z})$.

\section{Discussion}

The effects of TDH on undifferentiated and welldifferentiated human colonic cells prepared by different culture methods were investigated. Caco-2 cells differentiated towards villus-like cells after exposure to butyrate, by co-culturing with $18 \mathrm{Co}$ cells, or both, whereas T84 cells cultured by the same methods 

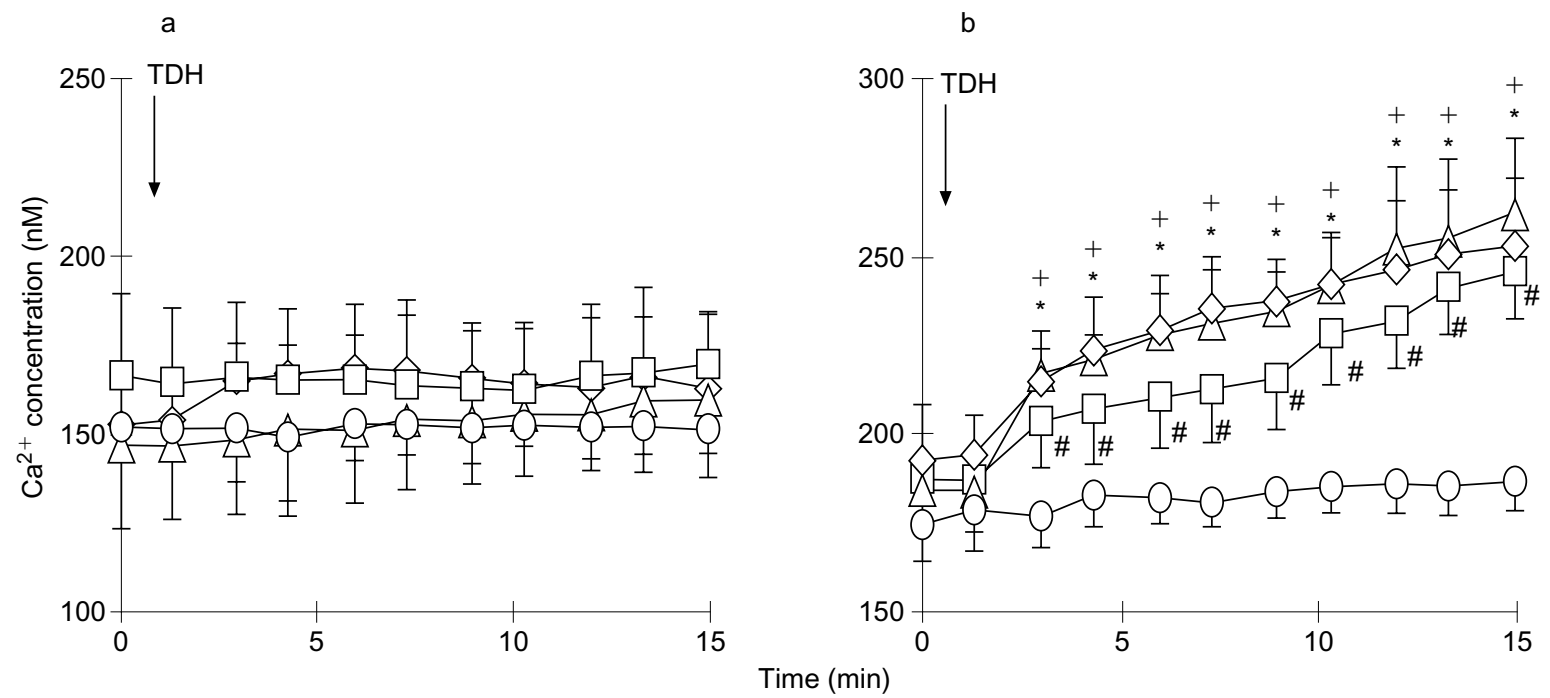

Fig. 6. Changes in the intracellular $\mathrm{Ca}^{2+}$ concentration after addition of TDH $10 \mu \mathrm{g} / \mathrm{ml}$. TDH was added at the points indicated. (a) T84 cells; (b) Caco-2 cells. 0, T84 cells or Caco-2 cells cultured on coverslips for 6 days; $\square$, T84 cells or Caco-2 cells were cultured on coverslips for 6 days then butyrate was added and cells were cultured for a further 2 days; \#significant difference $\mathrm{p}<0.05$ ( $t$ test) versus $\bigcirc$ value at each time. $\Delta$, T84 cells or Caco-2 cells cultured with 18 Co cells for 6 days; ${ }^{+}$significant difference $\mathrm{p}<0.05$ ( $t$ test) versus $\bigcirc$ value at each time. $\diamond$, T84 cells or Caco- 2 cells cultured with $18 \mathrm{Co}$ cells for 6 days then butyrate was added and cells were cultured for a further 2 days; ${ }^{*}$ significant difference $\mathrm{p}<0.05$ ( $t$ test) versus $\bigcirc$ at each time. The data were collected every $30 \mathrm{~s}$, but the values presented are the averages over $90 \mathrm{~s}$. Values are expressed as mean and SD $(n=7)$.

showed a much lower degree of differentiation towards villus-like cells. Furthermore, Caco-2 cells that were co-cultured with $18 \mathrm{Co}$ cells and exposed to butyrate showed higher alkaline phosphatase activities and sucrase activities than Caco- 2 cells that were exposed to butyrate without co-culturing. Thus, it is possible that the differentiation induced by exposure to butyrate and co-culturing with $18 \mathrm{Co}$ cells are different. These data confirm previous reports that butyrate or $18 \mathrm{Co}$ cells enhance cell differentiation to villus-like cells $[12,14,17,19,29]$, although the mechanisms are not completely understood. The methods used to produce five types of undifferentiated and three types of welldifferentiated colonic epithelial cell monolayers are described.

To evaluate the effect of TDH on colonic epithelial cells, $\left[\mathrm{Ca}^{2+}\right]_{\text {in }}$, TDH binding and Isc were measured the latter to provide evidence of $\mathrm{Cl}^{-}$secretion. After exposure to TDH, Isc and $\left[\mathrm{Ca}^{2+}\right]_{\text {in }}$ increased only in differentiated Caco- 2 cells. DIDS inhibited the increase in Isc brought about by exposure to $\mathrm{TDH}$, but glybenclamide and NPPB did not. These pharmacological profiles are the same as in previous findings that showed increased Isc after exposure to $\mathrm{TDH}$ in butyrate-treated Caco-2 cells [8]. Consequently, it is possible that the greater Isc detected in samples exposed to TDH is due to activation of $\mathrm{Ca}^{2+}$-activated $\mathrm{Cl}^{-}$channels. T84 cells that had been exposed to TDH showed very small changes in Isc and $\left[\mathrm{Ca}^{2+}\right]_{\text {in }}$. In this study, cells that were co-cultured with $18 \mathrm{Co}$ cells or exposed to butyrate were stimulated to develop villuslike cell functions as indicated by the type of enzyme activities found with villus cells $[14,15,19,21]$. This suggests that the $\mathrm{Cl}^{-}$secretion induced by TDH occurs in those cells that matured to become similar to epithelial villus cells.

There was greater binding of TDH to Caco-2 cells that had been stimulated to differentiate than to T84 cells or Caco-2 cells that had not been treated. This suggests that the expression of a receptor to which TDH can bind occurs during cell maturation. If the binding of TDH to cell receptors is the first step in the effect that TDH has on colonic epithelial cells, then the stimulation of $\mathrm{Cl}^{-}$secretion and the increase in $\left[\mathrm{Ca}^{2+}\right]_{\text {in }}$ may be regulated by binding of TDH to the cells during the process of cell differentiation.

It is generally accepted that butyrate induces cell differentiation that leads to the expression of villus-like enzymic and absorptive activity in vivo [18, 29, 30]. Butyrate does occur naturally in the normal human colon as a by-product of the metabolism by colonic bacterial flora of unabsorbed starch and non-starch polysaccharides, and this butyrate is used as an energy source by colonocytes [30]. Normal faecal levels of butyrate in man may be as high as $20 \mathrm{~mm}$ [18]. When butyrate is absent, as in the surgically excluded colon and in antibiotic therapy that destroys the intestinal mucosal flora, a syndrome known as diversion colitis ensues; this condition is ameliorated by the administration of butyrate [29]. Such evidence suggests that the butyrate is normally produced in vivo and affects intestinal epithelial cells.

$18 \mathrm{Co}$ is a human colonic myofibroblast cell line. Intestinal subepithelial myofibroblasts are found at the 
interface between enterocytes and the lamina propria $[12,19,31]$. Differentiation, proliferation and apoptosis of enterocytes and intestinal subepithelial myofibroblasts along the crypt-villus axis are spatially correlated in the human colon $[12,19,32]$. It has been suggested that intestinal subepithelial myofibroblasts secrete growth and differentiation factors that act on overlying epithelial cells [19, 33, 34].

Thus, it is likely that butyrate and subepithelial fibroblasts also regulate intestinal cell differentiation in vivo. Because the effects of TDH depend on the differentiation of colonic epithelial cells, it is plausible to suggest that manipulation of butyrate or the functions of subepithelial fibroblasts may alter the interaction of TDH and affect the symptoms caused by V. parahaemolyticus.

These studies were supported by a Grant-in-Aid to T.H. in the Research for the Future's program of the Japan Society for the Promotion of Science (JSPS-RFJF 97L00704).

\section{References}

1. Honda T, Chearskul S, Takeda Y, Miwatani T. Immunological methods for detection of Kanagawa phenomenon of Vibrio parahaemolyticus. J Clin Microbiol 1980; 11: 600-603.

2. Honda T, Iida T. The pathogenicity of Vibrio parahaemolyticus and the role of the thermostable direct haemolysin and related haemolysins. Rev Med Microbiol 1993; 4: 106-113.

3. Fabbri A, Falzano L, Frank C et al. Vibrio parahaemolyticus thermostable direct hemolysin modulates cytoskeletal organization and calcium homeostasis in intestinal cultured cells. Infect Immun 1999; 67: 1139-1148.

4. Nishibuchi M, Fasano A, Russell RG, Kaper JB. Enterotoxigenicity of Vibrio parahaemolyticus with and without genes encoding thermostable direct hemolysin. Infect Immun 1992; 60: $3539-3545$

5. Raimondi F, Kao JPY, Kaper JB, Guandalini S, Fasano A. Calcium-dependent intestinal chloride secretion by Vibrio parahaemolyticus thermostable direct hemolysin in a rabbit model. Gastroenterology 1995; 109: 381-386.

6. Huntley JS, Hall AC. Aspect of the haemolytic reaction induced by Kanagawa haemolysin of Vibrio parahaemolyticus. Toxicon 1994; 32: 1397-1412.

7. Tang G-Q, Iida T, Yamamoto K, Honda T. $\mathrm{Ca}^{2+}$-independent cytotoxicity of Vibrio parahaemolyticus thermostable direct hemolysin (TDH) on intestine 407, a cell line derived from human embryonic intestine. FEMS Microbiol Lett 1995; 134: $233-238$

8. Takahashi A, Sato Y, Shiomi Y et al. Mechanisms of $\mathrm{Cl}^{-}$ secretion induced by thermostable direct haemolysin of Vibrio parahaemolyticus in human colonic tissue and a human intestinal epithelial cell line. J Med Microbiol 2000; 49: $801-810$.

9. Levett PN, Daniel RR. Attachment of Vibrio parahaemolyticus strain to rabbit brush border membranes. Zentralbl Bakteriol Mikrobiol Hyg A 1988; 268: 245-250.

10. Akeda Y, Nagayama K, Yamamoto K, Honda T. Invasive phenotype of Vibrio parahaemolyticus. J Infect Dis 1997; 176: $822-824$.

11. Pinto M, Robine-Leon S, Appay MD et al. Enterocyte-like differentiation and polarization of the human colon carcinoma cell line Caco-2 in culture. Biol Cell 1983; 47: 323-330.

12. Yamamoto T, Yokota T. Adherence targets of Vibrio parahaemolyticus in human small intestines. Infect Immun 1989; 57: $2410-2419$.
13. McEwan GTA, Brown CDA, Hirst BH, Simmons NL. Kanagawa haemolysin of Vibrio parahaemolyticus stimulates transepithelial $\mathrm{Cl}^{-}$secretion in human intestinal T84 epithelial cell layers. J Physiol 1994; 475P (Proceedings): 92P.

14. Jacewicz MS, Acheson DWK, Mobassaleh M, Donohue-Rolf A, Balasubramanian KA, Keusch GT. Maturational regulation of globotriaosylceramide, the Shiga-like toxin 1 receptor, in cultured human gut epithelial cells. J Clin Invest 1995; 96: $1328-1335$.

15. Matsumoto h, Erikson RH, Gum JR, Yoshioka M, Gum E, Kim YS. Biosynthesis of alkaline phosphatase during differentiation of the human colon cancer cell line Caco-2 cells. Gastroenterology 1990; 98: 1199-1207.

16. Agarwal VP, Schimmel EM. Diversion colitis: a nutritional deficiency syndrome? Nutr Rev 1989; 47: 257-261.

17. Chung YS, Song IS, Erikson RH, Sleisenger MH, Kim YS. Effect of growth and sodium butyrate on brush border membrane-associated hydrolases in human colorectal cancer cell lines. Cancer Res 1985; 45: 2976-2982.

18. Cummings JH, Pomare EW, Branch WJ, Naylor CPE, Macfarlane GT. Short chain fatty acids in human large intestine, portal, hepatic and venous blood. Gut 1987; 28: $1221-1227$.

19. Powell DW, Mifflin RC, Valentich JD, Crowe SE, Saada JI, West AB. Myofibroblasts. I. Paracrine cells important in health and disease. Am J Physiol 1999; 277: C1-C19.

20. Valentich JD, Popov V, Saada JI, Powell DW. Phenotypic characterization of an intestinal subepithelial myofibroblast cell line. Am J Physiol 1997; 272: C1513-C1524.

21. Hauri HP, Sterchi EE, Bienz D, Fransen JAM, Marxer A. Expression and intracellular transport of microvillus membrane hydrolases in human intestinal epithelial cells. $J$ Cell Biol 1985; 101: 838-851.

22. Yoh M, Honda T, Miwatani T, Nishibuchi M. Characterization of thermostable direct hemolysins encoded by four representative $t d h$ genes of Vibrio parahaemolyticus. Microb Pathog 1991; 10: 165-172.

23. Iida $T$, Yamamoto K. Cloning and expression of two genes encoding highly homologous hemolysins from Kanagawaphenomenon-positive Vibrio parahaemolyticus T-4750 strain. Gene 1990; 93: 9-15.

24. Laemmli UK. Cleavage of structural proteins during the assembly of the head of bacteriophage T4. Nature 1970; 227: 680-685.

25. Cunningham SA, Worrell RT, Benos DJ, Frizzell RA. cAMPstimulated ion currents in Xenopus oocytes expressing CFTR cRNA. Am J Physiol 1992; 262: C783-C788.

26. Inoue CN, Woo JS, Schwiebert EM et al. Role of purinergic receptors in chloride secretion in Caco-2 cells. Am J Physiol 1997; 272: C1862-C1870.

27. Schultz BD, Singh AK, Devor DC, Bridges RJ. Pharmacology of CFTR chloride channel activity. Physiol Rev 1999; 79 (1 Suppl): S109-S144.

28. Sheppard DN, Welsh MJ. Inhibition of the cystic fibrosis transmembrane conductance regulator by ATP-sensitive $\mathrm{K}^{+}$ channel regulators. Ann NY Acad Sci 1993; 707: 275-284.

29. Augeron C, Laboisse CL. Emergence of permanently differentiated cell clones in a human colonic cell line in culture after treatment with sodium butyrate. Cancer Res 1984; 44: 3961-3969.

30. Scheppach W. Effects of short chain fatty acids on gut morphology and function. Gut 1994; 35 Suppl 1: S35-S38.

31. Dharmsathaphorn K, McRoberts JA, Mandel KG, Tisdale LD, Masui h. A human colonic tumor cell line that maintains vectorial electrolyte transport. Am J Physiol 1984; 246: G204-G208.

32. Hall PA, Coates PJ, Ansari B, Hopwood D. Regulation of cell number in the mammalian gastrointestinal tract: the importance of apoptosis. J Cell Sci 1994; 107: 3569-3577.

33. Evans GS, Flint N, Tait I, Campbell FC. Epithelial mesenchymal interactions in intestinal epithelial proliferation in vitro. Gut 1993; 34 Suppl 1: S7.

34. Graham MF, Diegelmann RF, Elson CO, Bitar KN, Ehrlich HP. Isolation and culture of human intestinal smooth muscle cells. Proc Soc Exp Biol Med 1984; 176: 503-507. 